ISSN: 2165-8714

http://www.eu-jer.com/

\title{
Assessment of the Practices for Early Mathematics Thinking in Preschools of Pasaje City, Ecuador
}

\author{
Clelia Consuelo \\ Reyes-Cedeno \\ Technical University of \\ Machala, ECUADOR
}

\author{
Hector Ivan Rivas-Cun \\ Technical University of \\ Machala, ECUADOR
}

\author{
Carmen Elizabeth \\ Espinoza-Cevallos \\ Technical University of \\ Machala, ECUADOR
}

\author{
Carlos R. Rojas-Garcia* \\ Technical University of \\ Machala, ECUADOR
}

Received: June 24, 2019 - Revised: August 31, 2019 - Accepted: September 10, 2019

\begin{abstract}
Preschool education is fundamental to shape children's aptitudes and skills in early life. Ecuador is following a global education trend for starting-up mathematical thinking at earlier development ages, but this is only reflected in vehement curricular changes that are not supported properly. As a result, the safeguarding of a good children's education appears to be lessened. This work aimed to evaluate the mathematics thinking practices in preschools of Pasaje city, Ecuador. The investigation employed a descriptive approach, hence data were collected from 65 teachers and 810 parents from public and private preschools by means of interviews and questionnaire in an attempt define some causes (teacher's education, children's socio-economical and family circumstances) that impair the initiation of the numerical, spatial and metric and geometric aptitudes in children. The results showed that not only preschool practices but also the home environment linked to socio-economic status appear to have positive or unfavorable influences on their children's education.
\end{abstract}

Keywords: Preschool curriculum, mathematical thinking, parents' literacy, socio-economical status.

To cite this article: Reyes-Cedeno, C. C., Rivas-Cun, H. I., Espinoza-Cevallos, C. E., \& Rojas-Garcia, C. R. (2019). Assessment of the practices for early mathematics thinking in preschools of Pasaje city, Ecuador. European Journal of Educational Research, 8(4), 10631070. https://doi.org/10.12973/eu-jer.8.4.1063

\section{Introduction}

The dictionary form for the word "kindergarten" denotes a preschool playgroup and also defines its main attribute "a place to play" where game activities are essential practices. Preschool instruction is fundamental to shape children's aptitudes and skills, offering the elementary tools to access future educational levels (Espinoza, 2018). In Scandinavian countries, the views and attitudes of preschool teachers follow a basic common answer "mathematics is everywhere and is something we use every day" (Benz, 2012; Lee \& Ginsburg 2007). Mathematically oriented activities play important roles as a formative instrument at preschool (Initial Education, 2005); also helping the children to improve rational thinking to access learning information.

As a rule of thumb, curriculum developers include lessons focusing on rational awareness for preschool education, but in the Ecuadorian context, something that should mean became a mandatory end. Nevertheless, due to the bad results of the rational and mathematical thinking components of preschool's curriculum, these topics have lost importance in preschool practices. In this context, the Ministry for Education has engaged in a permanent searching for strategies to educate the population on the transfer of good capabilities so they can live in a learning technology society ([Ecuadorian Ministry of Education] MEE, 2014). In Ecuador during the so-called "Citizens' Revolution", the preschool curricula have changed drastically (but were not properly strengthened), and as a consequence, the official claims for safeguarding a good education from childhood to adulthood (higher education) were weakened. Several incongruences still surrounds the praxis in Ecuadorian preschools, where the accelerated changes in the curricula do not correspond with human socio-economical situations of teachers and parents such as inconsistences and problems that are consequences of the reforms design, its implementation and structural and historical circumstances (Guayasamin, 2016) among which the acquisitions of skills by teachers ("teachers do not understand the importance of mathematical thinking or do not understand what it really is" Katagiri, 2004, chapter 2) and a lack of understanding of the reasons for such changes (society). Authors suggest that Correa's reforms from 2006 to 2017 were a negative example of top-down reform lacking the construction of an ample coalition of unions with strong social support (Schneider, Cevallos \& Burns,

\footnotetext{
* Corresponding author:

Carlos R. Rojas-Garcia, Boca del Rio 94297, Veracruz, Mexico. $₫$ rocarlo@protonmail.com
} 
2017). The incoherence begins from the very scientific grounds. For example, the cognitive development of young children has scarcely been studied in Ecuador and practically does not exist in reports, nor in the socio-economical and family circumstances (poor or wealthy; rural or urban). Similarly, the lack of socio-pedagogical research that combines theory with practice in the formation and development of mathematical thinking in preschool is rare. These combined circumstances form an enormous contradiction in educational policies pretending that effective mathematic thinking in preschool will construct the better citizens that the country needs. The fails are evident. For instance, undeveloped mathematical thinking in older children still occurring in basic education schools (Espinoza, 2018) and typified by the fails in mathematical language and unfamiliarity of metrics. Deficiency in numerical thinking (counting), in spatial awareness and geometric systems, among other circumstances.

\section{Theoretical framework}

Preschool education is the start-up for children's cognitive growth and requires unique pedagogical foundations according to their short age, as well as solid didactic methods by teachers. Authors such as Fernandez (2003), Ortiz (2002), Ruesga ( 2011), Siegler and Svetina (2002), Tobon (2012), Valencia and Galeano (2005) and Villegas (2011), made contributions on various factors involving intellectual, motoric, artistic, child games and children thinking.

With regard to mental growth, it has been determined that the development of logical thinking requires the acquisition of rising reasoning levels, interpretation, argumentation and the ability to plan proposals and alternative solutions to any type of difficulty/conflict that the child confronts every day (Valencia \& Galeano, 2005). Similarly, Bishop (1999), Fernandez (2003) and Ruesga (2011) went deep into the singularities of mathematical thinking at early ages. The comprehension of mathematical actions by children depends on their level of cognitive development, and it can be stimulated by mathematical logical activity, as well as analytical capacity and assertiveness such as confidence in their own abilities, perseverance in the search for solutions and the pleasure to learn. By developing mathematical reasoning children can develop their normal and abstract thinking in a coherent pathway. The associations established by children within different life atmospheres permit them to acquire life experiences for future school life (Villegas, 2011).

It can be stated that mathematical thinking is unique quality in each child and is built according to their own infant experiences, these conditions represent a challenge for teachers who must meet the cognitive needs for every child according to their individual learning styles, but the combined actions child-teacher can trigger meaningful experiences. According to Tobon (2012), "starting-up from simple things such as buying, playing, measuring, singing, selecting, the child will be able to develop logical thinking skills" (p. 13).

There are different theoretical frameworks to address the development of children's mathematical thinking. Such as the Japanese scholastic approach (Katagiri, 2004) or as a cultural-historical point of view as in the Netherlands (based on Vygotsky`s theory) that has generated educational approaches under the play perspective and the imitative participation (Van Oers, 2010, 2012). In the Ecuadorian context the beliefs of a hidden mathematical talent in every child must not be applied arbitrarily as a constructivist assumption (Cobb, 1994) or pseudoconcept, on the contrary can only be encouraged (if it is socially relevant and accepted), also in an amusing way according to the natural infant behavior and social context.

In Latin American countries the direct importation (copy-paste) of foreign teaching stereotypes is a common bureaucratic practice; a sort of 'pedagogical cloning' that attempts to replicate innate geniuses (chess players, violinists, numerologists or scientists), pretending that filling-up a country with mathematicians will improve the economy and general welfare. There are examples of mismatching for the copy-paste practices that can not meet the real context within a developing country, such as the of use of drastic mathematical concepts forced to fit-in the preschool curriculum, for instance, the case of Valencia and Galeano (2005) who recommend elusive components to address the initiation of mathematical thinking.

- Numerical thinking: the intuitive concept of numbers thinking and counting tasks, organization and sequence with different elements.

- Geometric spatial thinking: to provide the ability for examining and analyzing the properties of two dimensional and three-dimensional spaces, as well as the shapes and figures present inside, by spontaneous and amusing activity.

- Metric thinking and measurement system: to approach the process of measuring physical elements and comparing them; which one is longer or shorter? etc.

The same authors (Valencia \& Galeano, 2005), suggest for the starting-up of mathematical thinking in preschool the following operations would be included : (1) Classification, that lies in learning to group objects according to one or more conditions or qualities: For instance, to classify objects present in the environment by color and to make subgroups having the same qualities; (2) Seriation, that consist of ordering objects according to a pattern: For instance, order from highest to lowest; (3) The number, that is the acceptance that the number is a property of the groups; (4) Representation, a sort of inner mirroring of the outside world based on the principle of conservation of Piaget, that objects exist despite not being present at any given time. The preschool children can exercise the representation through: (i) Imitation of an act of supposition; (ii) Serial representation: Objects sorting according some of its parts; (iii) 
Allegorical representation: Sorting bi-dimensional objects by drawing; (iv) Codification: Arbitrary classification shared by society through the word, number or graph.

Other forms of logical teaching practices for starting-up mathematical thinking are the awareness of space and the understanding of time. Regarding space, the child constructs notions, relationships and structures of the objects that surround him. The understanding of time is related to the physical and social knowledge of the child at the moment in which it constructs events and attends to a logical and chronological sequence of events. Valencia and Galeano, 2005 (p.250) suggests the following preschool activities: (a) Perform some operations between groups; (b) Recognize, analyze and symbolize certain relationships between elements in a numerical group from 1 to 99; (c) Use addition and subtraction of numbers from 0 to 99; (d) Differentiate problems that pose an additive situation and give solution.

Luckily, on the other hand, there exist normal methods for triggering mathematical thinking that come naturally from the child's behavior such as liking to play which is an inherent activity in childhood, but also the best way to get in contact with objects and other infants, to stimulate children learning and delineate their character (Claro, 2013). It has been proved that to play is one of the six cultural activities motivating the development of mathematical ideas, the other five are counting, measuring, locating, designing and explaining. In addition, the play promotes communication skills, sets-up challenges, generates situations of doubt and develops reasoning (Bishop, 1999, Fernandes et al. 2017). Also, children use games to define and respect rules and to become predisposed to discipline. Therefore, it is indispensable to introduce game activities to help the most basic and natural aspects (counting, measuring and shaping) of the child's reasoning in preschool. For example, it can be done by making simple questions such as where is more or where is less (Garcia \& Perez, 2011). Throughout playing games, the boy and the girl can interact with the surrounding world to shape their own learning ([National Ministry of Education] MEN, 1998). Parents and teachers can use the game activity to guide the first steps in mathematical learning (De Souza, Concentino, Bazan \& Luccas, 2017), a positive teacher-child association for game/learning (which remains to be developed) could be a useful tool for the development of mathematical thinking in preschool in Ecuador.

\section{Methodology}

\section{Research goal}

The objective of this research was to evaluate the mathematical thinking practices in preschools of Pasaje city, Ecuador. The researchers expected to get insights in the social-economic factor influencing teacher attitudes (low salaries) and home circumstances (good or poor welfare). Various concerns were identified from participants' responses, exposing the obstacles that teachers and children encounter during the starting-up of mathematical thinking of the children.

\section{Participants}

The total participants' population was obtained from preschool records or another direct counting.

The participants were 104 teachers and 986 parents that belong to the 54 preschools (including the respective children groups, 3-5 years old) in Pasaje city. From this participant's population, a stratified working sample was constituted by 65 teachers and 810 parents randomly selected to guarantee the representativeness of each school, at least one teacher and 15 parents per school. In this way, 357 parents correspond to private schools and 453 to public schools.

\section{Data Collection}

The research data was obtained by interviews and questionnaires. A simple protocol was used to collect, process and analyze the data, the interviews and opinions from teachers and parents. The regular teaching practices in local preschools, the components and practices involved were identified by means of systematic observation. The interviews with parents and teachers were conducted to determine whether if both were qualified or not for children's tuition during this stage. The interview questions presented to teachers were a modification to those proposed by Acosta de la Cueva (2010).

\section{Procedure}

In order to avoid gathering biased data, the interviews with parents, teachers and the classroom observations were performed by 8 social workers trained particularly for this specific interview and nobody of them worked in Pasaje city. In the interview to the parents, the examiners verified (using impartial questioning) the literacy level of the parents and their aptitudes for didactic interventions in support of the stating-up of mathematical thinking. The direct observations of teaching activities in the classroom allowed the diagnosis of the starting-up mathematical thinking in children as adequate or inappropriate. The teaching practices in the classroom were evaluated by impartial social workers with groups of 22 to 30 infants (from private and public school respectively) with the supervision of the preschool principal. The observers focused on dichotomous responses, adequate or inadequate according to the following mathematical cases: 
- Numerical thinking: The children performed operations between simple groups including to recognize, analyze and represent some relationships between the elements of the numerical group from 1 to 99 , to use addition and subtraction, in the group of numbers from 0 to 99 (distinguish problems and give solution).

- Metric thinking, the activities took into consideration: (1) To establish comparison relationships between elements and conclude which one is longer or shorter; (2) To measure the length of some elements with unconventional tools and conclude which one is longer or shorter.

- Geometric spatial thinking: Evaluated by the children's performance of some topological spatial relationships, recognize and classify solids and flat surfaces, start the recognition of the concept of symmetry from certain regularities present in bodies and figures.

The parents' interviews focused on their literacy for tuition the start-up of mathematical awareness in their children. The parameter evaluated were (I) parents with good literacy, (II) parents with understanding how to stimulate the mathematical thinking of their children, (III) parents who assist the children's study activities and attend to their concerns and (IV) the quality of life in affective terms: the child feels respected, loved and protected in home environment.

\section{Analyzing of Data}

As the research adopted a simple descriptive approach. The data collected was computed with standard spreadsheets for basic descriptive statistics and presented in tables and graphs.

\section{Results}

The results are exposed and analyzed below.

Table 1. Diagnosis of game practices for promoting the children mathematical thinking.

\begin{tabular}{|c|c|c|c|c|c|c|}
\hline Questions & Always & $\%$ & Sometimes & $\%$ & Never & $\%$ \\
\hline $\begin{array}{l}\text { ¿Do you use game activities for } \\
\text { stating-up the children's interest for } \\
\text { mathematics? }\end{array}$ & 0 & 0 & 63 & 96.9 & 2 & 3.1 \\
\hline $\begin{array}{l}\text { ¿Do you use games during class to make } \\
\text { mathematics learning enjoyable? }\end{array}$ & 0 & 0 & 23 & 35.4 & 42 & 64.6 \\
\hline $\begin{array}{l}\text { ¿Is the official textbook a good support for } \\
\text { developing mathematical thinking? }\end{array}$ & 0 & 0 & 65 & 100 & 0 & 0 \\
\hline $\begin{array}{l}\text { ¿Is the mathematical thinking of children a } \\
\text { conscious activity in classes and home } \\
\text { activities? }\end{array}$ & 0 & 0 & 11 & 16.9 & 54 & 83.1 \\
\hline $\begin{array}{l}\text { ¿Are mathematics an enjoyable class for } \\
\text { children? }\end{array}$ & 0 & 0 & 9 & 13.8 & 56 & 86.2 \\
\hline $\begin{array}{l}\text { ¿Do you consider necessary to have an official } \\
\text { strategy to guide the activities for starting-up } \\
\text { development the mathematical thinking in } \\
\text { preschool? }\end{array}$ & 53 & 81.5 & 12 & 18.5 & 0 & 0 \\
\hline
\end{tabular}

Table prepared by author; questions based on Acosta de la Cueva (2010) with modifications.

According with Table 1, it has clearly showed the scarce systematization of game and amusing practices adopted by teachers to prompt mathematical responsiveness, which in turn caused rejection of mathematic topics by children. Teachers did not apply innovative practices in the class to stimulate mathematical thinking. Secondly, the preschool textbook had a low or erroneous use according to the evaluators.

Teachers consensus for mathematics in preschool.

Figure 1. Teachers consensus for initiation mathematical thinking in preschool children.

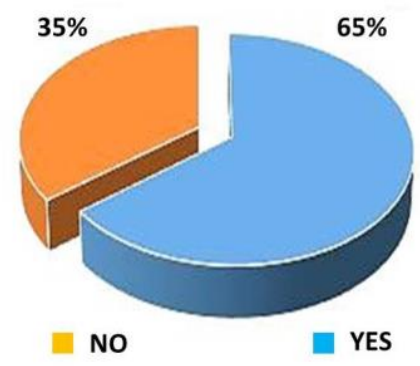


Figure 1. Teachers consensus for initiation of mathematical thinking in preschool children.

Oddly enough, in the teacher community there was a consensus for initiation of mathematical reasoning and thinking in pre-school children as shows Figure 1.

The interview conducted by trained observers to the 810 parents revealed the information presented in Table 2

Table 2. Parents literacy as support for the start-up of mathematical awareness in their children.

\begin{tabular}{lcc}
\hline \multicolumn{1}{c}{ Parameters } & Number & \% \\
\hline Parents with good literacy & 326 & 40.2 \\
Parents with understanding for encouraging mathematical thinking of their children & 305 & 37.7 \\
$\begin{array}{l}\text { Parents whom support their children's homework activities and respond to their } \\
\text { concerns }\end{array}$ & 421 & 52.0 \\
$\begin{array}{l}\text { Parents whom offer a good quality of life in emotional terms: the children can feel } \\
\text { respect, love and protection in the home environment. }\end{array}$ & 687 & 84.8 \\
\hline
\end{tabular}

$$
\text { Table prepared by author. }
$$

There was correspondence between the parents' literacy and the good study performance of their children, including mathematics related classes. Diagnosis of children's mathematical awareness by school type private or public

Table 3. Parents literacy and school type.

Table 3. Parents literacy and school type.

\begin{tabular}{lccc}
\hline \multicolumn{1}{c}{ Parameters } & \multicolumn{2}{c}{$\begin{array}{c}\text { Private preschools } \\
\text { Number }\end{array}$} & \multicolumn{2}{c}{$\begin{array}{c}\text { Public preschool } \\
\text { Number }\end{array}$} & \% \\
\hline $\begin{array}{l}\text { Parents with good literacy } \\
\text { Parents with understanding for encouraging mathematical thinking } \\
\text { of their children }\end{array}$ & 278 & 77.9 & 217 \\
$\begin{array}{l}\text { Parents whom support their children's homework activities and } \\
\text { respond to their concerns }\end{array}$ & 223 & 62.5 & 167 \\
$\begin{array}{l}\text { Parents whom offer a good quality of life in emotional terms: the } \\
\text { children can feel respect, love and protection in the home } \\
\text { environment. }\end{array}$ & 36.9 & 83.2 & 276 \\
\hline
\end{tabular}

Table prepared by author.

The information showed different effects in children`s mathematical responsiveness concerning the home atmosphere, private schools and public schools that suggest a correlation between quality of preschool and cognitive development of preschool children.

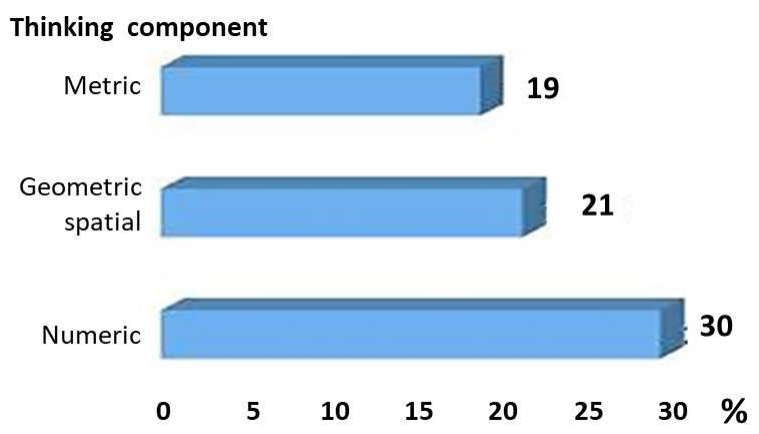

Figure 2. Mathematical thinking components.

The observations of the teaching-learning practices of 65 selected teachers ( 65 group classes), revealed limitations in the didactic activities for stimulation of mathematical awareness with deficiencies in all components of children's mathematical skills such as adding or subtracting, measuring, objects and figures symmetry, representation of the things from the surrounding world by simple mathematical notions 


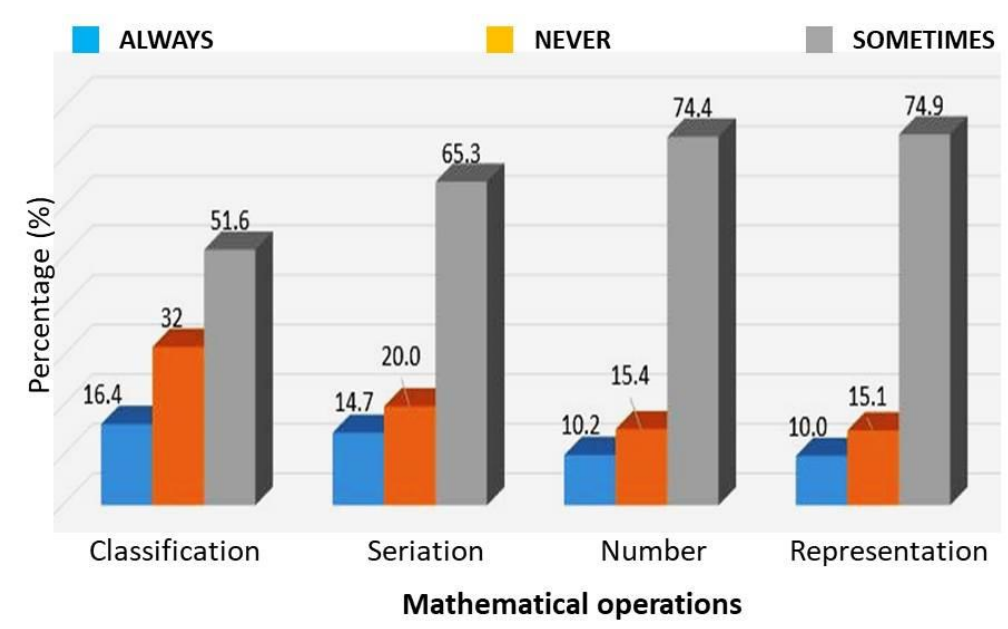

Figure 3. Teacher practices for developing mathematical thinking skills.

Figure 3 show low teaching performance in pedagogical practices for promoting mathematical operations of the preschool students. The number concept had a negative appreciation and consequently the seriation and classification components of mathematical thinking were negatively affected. Similar occurred with the representation component; if the children lack abilities to enumerate, measure or classify, mathematical games could also be perceived as less amusing. .

\section{Discussion}

The diagnosis of preschool teachers for perceptions and practices in mathematics combines aspects from classroom tasks to classroom interactions. The preschool teacher's perceptive consensus for the starting-up of mathematical thinking in preschool partially agreed with Acosta de la Cueva (2010 p.34), who recognized the teacher`s importance to stimulate and guide the children in this class. However, the consensus was contrary to Barnett (2004) who focused on the importance of the teacher`s training for better preschool practices, here in the Pasaje`s teachers fell evidently short on theoretical and practical basis to achieve this goal. The proficiency of preschool teachers had been perceived as defective in Ecuador (Fabara, 2013). However, this fact can not be the unique cause of the deficiencies occurring in Pasaje preschools. For example, in Japan for 45 years the teaching of mathematical thinking was by no means sufficient and far from suitable in reality (Katagiri, 2004). Concerning the children's home context, Avalos et al. (2018) also considered that a good family context is indispensable in the integral formation of the child. Consequently, a family`s aspects such as affective, cognitive, psychological and social factors must be taken into account. In the cognitive part concrete actions are required to enhance the children's attitudes, while the affective area deals with emotional control to manage love or anger (p. 2). The parents' views pretended (a false belief) to offer good home environment (respect and protection) for their children. However, the results suggest constraints in the home environment that frustrate a good support for starting-up the children's mathematical thinking. On the other hand, the preschool quality and good cognitive development of children seem to be related as occurring in other countries (Tomar \& Kumari, 2017).

The observations of teachers performing mathematical game activities showed overprotective and incorrect guidance, without freedom from teacher's control when they perform mathematical tasks and games. This was contrary to the finding by Wing and Beal (2004) where preschool children were successful at similar tasks when were prompted by teachers. The inter-subjectivity incidence when children are required to think freely or solve the classroom tasks has been reported in other countries (Nurlaily, Soegiyanto \& Usodo, 2019), the overprotection could represent an indeterminate factor in delaying the typical development of mathematical thinking of preschool children.

McMullen, Hannula-Sormunen, and Lehtinen (2013) show there was a significant increase in the use of quantitative relations with age as they acquire the sense and command of numbers. This lack of teacher's prompting could be a difference in the experimental settings between the current study and previous studies of children's reasoning about numbers, metrics and forms which may have caused inconsistencies in the use of mathematical thinking. Assessing children's mathematical thinking is a complex task in terms of teaching. This requires understandings and theories about young children, learning and teaching. The evaluators were trained to avoid inter-subjectivity, however, it can not be said whether the children feel comfortable in expressing their learning in the presence of strangers (evaluator) and authorities (the school principal) or not.

\section{Conclusion}

This work was a preliminary diagnosis of the pedagogical practices and parents tuition aptitudes to promote the starting-up of mathematical thinking in pre-school children and found the following barriers and deficiencies:

- Insufficient teaching training for including game practices. 
- Erroneous use of the official textbook.

- Short methodological resources by the teacher

- Differences in family welfare, parent literacy and parental tuition.

These social, psychological and pedagogical deficiencies could diminish the acquisition of initial mathematical skills and block continuity in later basic school education.

On the other hand, the necessity of mathematics training programs for preschool teachers, and the socio-economical family circumstances play a role that remains to be examined.

\section{References}

Acosta de la Cueva, J. K. (2010). Elaboracion de una guia metodologica para el desarrollo de la inteligencia logico matematica en ninos y ninas de 5 anos de edad de la escuela "Juan Montalvo" de la provincia Pichincha canton Ruminahui durante el 2009-2010 [Elaboration of a methodological guide for the mathematical-logical intelligency development of 5 years old children in the school "Juan Montalvo" Pichincha province Ruminahui community]. Benz, C. (2012). Attitudes of kindergarten educators about math. Journal fur Mathematik-Didaktik, 33(2), 203-232

Bishop, A. (1999). Enculturacion matematica [Mathematics culture acquisition]. Madrid, Spain: Paidos.

Claro, J. (2013). Calidad en educacion y clima escolar: apuntes generales [Education quality and school environment: general notes]. Estudios Pedagogicos, 39(1).

Cobb, P. (1994). Where is the mind? Constructivist and sociocultural perspectives on mathematical development source: Educational Researcher 23, pp. 13-20. Published by: American Educational Research Association.De Souza, B. B., Concentino, J., Bazan, B. M., \& Luccas, S. (2017). Os jogos matematicos podem auxiliar a discalculia? [Can math games help to dyscalculate?]. Revista Espacios, 38(35).

Educacion Inicial (2005). Procesos Matematicos: Dirigido a docentes y otros adultos significativos que atienden niños y niñas entre 0 y 6 años [Mathematical Processes: For teachers and adults who attend children between 0 and 6 years]. Retrieved from: http://portaleducativo.edu.ve/Politicas_edu/...

Espinoza, E. (2018). Presencia de los metodos problemicos en la educacion basica [Presence of problem methods in basic education].Mendive. Revista de Educacion, 16(2), 262-277.

Fabara, E. (2013). Estado del arte de la formacion docente en el Ecuador [State of the art of teacher training in Ecuador]. Quito: Contrato Social por la Educacion [Quito: Social Contract for Education], Retrieved from http://www.campanaderechoeducacion.org/sam2013/wpcontent/uploads/20 13/04/formacion_docente.pdf

Fernandes, K. B., Botelho De Moraes, A., Blumetti, F. J., Acacio, A. A., \& Candiago, A. (2017). Serious games como ferramenta de apoio ao ensino das quatro operações matematicas para crianças [Truthful games as a support to teach four math operation for children]. Revista Espacios, 38(30), 29-46.

Fernandez, B. J. A. (2003). La construccion del pensamiento logico-matematico [The construction of mathematical thinking]. Centro Universitario de Ensenanza Superior "Don Bosco", Madrid, Espana. Congreso Internacional Cerebro, Inteligencias y Programas Educativos. Educacion de la Infancia Inicial y Parvulario [University Center for Higher Education "Don Bosco", Madrid, Spain. International Congress Brain, Intelligence and Educational Programs. Early Childhood and Nursery Education]. El Salvador. Retrieved from: http://www.waece.org/memoriascongresos/cong2003elsalvador/textos/fernandezbravo.htm

Garcia, 0., \& Perez, J. (2011). Secuencia didactica: los contextos numericos como forma de fortalecer el concepto de número en grado transicion [Didactic sequence: the numerical contexts as a way to strengthen the concept of number in degree transition]. Valley University, Cali, Colombia. Retrieved from: http://bibliotecadigital.univalle.edu.co/bitstream/10893/3850/4/CB-0449641.pdf

Katagiri, S. (2004). Mathematical thinking and how to teach it. CRICED, University of Tsukuba.

Lee, S. L., \& Ginsburg, H. P. (2007). What is appropriate mathematics education for four year-olds? Pre-kindergarten teachers' belief. Journal of Early Childhood Research, 5(1), 2-31.

McMullen, J., Hannula-Sormunen, M.M., \& Lehtinen, E. (2013). Young children's recognition of quantitative relations in mathematically unspecified settings. Journal of Mathematical Behavior, 32(3), 450-460.

MEE (2014). Actualizacion y Fortalecimiento Curricular de Educacion General Basica [Curriculum Update and Strengthening of Basic General Education]. Ministerio de Educacion del Ecuador [Ecuadorian Ministry of Education ] . D.M. Quito. Retrieved from: www.forosecuador.ec/.../ecuador/educacion.../1143-actualizacion-yfortalecimiento 
MEN (1998). Lineamientos Curriculares de Matematica [Curricular Mathematics Guidelines]. Santafe de Bogota, Colombia. Retrieved from: http://map.upb.edu.co/rid=1HQVXB4Q7.../LINEAMIENTOS\%20CURRICULARES.pps

Nurlaily, V.A., Soegiyanto, H., \& Usodo, B. (2019). Elementary school teacher's obstacles in the implementation of problem-based learning model in mathematics learning. Journal on Mathematics Education, 10(2), $229-238$.

Ortiz, L. (2002). La insercion curricular de estrategias de aprendizaje en Educacion Infantil. Fundamentos teoricos [The curricular insertion of learning strategies in Early Childhood Education.Theoretical fundaments] . Actas del II Congreso Internacional de Educacion Infantil [Proceedings of the II International Congress of Child Education], (pp. 377-382). Granada, Spain.

Ruesga, R. P. (2011). Educacion del razonamiento logico matematico en educacion infantil [Teaching logical mathematical reasoning in early childhood education]. (Unpublished Doctoral Thesis). Barcelona University.

Siegler, R. S., \& Svetina, M. (2002). A microgenetic/cross-sectional study of matrix completion: comparing short-term and long-term change. Chil Development, 73(3), 793-809.

Tobon, O. N. (2012). Aventura por las Matematicas. "Estrategias Pedagogicas- Didacticas para Desarrollar el Pensamiento Logico Matematico en los ninos de 3- 4 anos, del hogar Campanitas" [Mathematics Adventure. "Pedagogical-Didactic Strategies to Develop Mathematical Logical Thought in children aged 3-4 years, from the Campanitas home". (Unpublished diploma thesis).Lasallian University Corporation Faculty of Social Sciences and Education. Caldas. Retrieved from: https://es.scribd.com/.../123-UNA-AVENTURA-POR-LAS-MATEMATICAS-pdf

Schneider, B.S., Cevallos, P., \& Burns, B. (2017). The Politics of Transforming Education in Ecuador: Confrontation and Continuity.

Tomar, R., \& Kumari, A. (2017). Cognitive development of children in private franchise preschool. International Journal of Recent Scientific Research 8, 15494-15499.

Valencia, C. G., \& Galeano, U. B. D. (2005). Aprestamiento de la Logica Matematica [Acquisition of Mathematical Logic]. Guia Didactica y Modulo Fundacion Universitaria "Luis Amigo" [Didactic Guide and Module University Foundation "Luis Amigo"]. Education Faculty, Medellin Colombia.

Van Oers, B. (2010). Emergent mathematical thinking in the context of play. Educational Studies in Mathematics, 74, 2337.

Van Oers, B. (2012). Meaningful Cultural Learning by Imitative Participation: The Case of Abstract Thinking in Primary School. Human Development, 55(3), 136-158.

Villegas, A. L. E. (2011). Investigacion sobre la etapa pre operacional y la nocion de conservacion de cantidad en niños de 3 a 5 años del Colegio San Jose de la Salle [Research on the pre-operational stage and the notion of quantity conservation in children aged 3 to 5 years of the San Jose de la Salle School].

Wing, R. E., \& Beal, C. R. (2004). Young children's judgments about the relative size of shared portions: The role of material type. Mathematical Thinking and Learning, 6, 1-14. 